\title{
MUZEUM ZORIENTOWANE NA ODBIORCE.. STRATEGIE EDUKACYJNE BUDUJĄCE DŁUGOOKRESOWE RELACJE Z WIDZEM JAKO USŁUGOBIORCA
}

\begin{abstract}
Rogozińska Anna, Muzeum zorientowane na odbiorcę. Strategie edukacyjne budujące długookresowe relacje z widzem jako ustugobiorca [The Museum as a Service Deliver and Visitor-Oriented Institution]. Studia Edukacyjne nr 41, 2016, Poznań 2016, pp. 323-334. Adam Mickiewicz University Press. ISSN 1233-6688. DOI: 10.14746/se.2016.41.20

This article discusses the role of marketing in the transformation of a museum. The museum should become a service organization with a diverse range of activities, concentred on the audience. There is a real chance that the introduction of relationship marketing in the museum will help it fulfil its mission. Relationship marketing treated as an approach which permeates the all institutional structures and helps to manage the whole museum: it is both the manager path, as well as all museum staff. This marketing is focused not only on promotion and communication, but is also used in shaping the museum educational strategies and planning further institutional activities. From this perspective, marketing is an orientation and a set of specialized practices, it has become a way to understand common values and to achieve specific goals.
\end{abstract}

Key words: museum audience, educational strategy, museum delivers, relationship marketing, service marketing

Świat sztuki ukształtowany pod koniec XX wieku w Europie Zachodniej, Stanach Zjednoczonych i Australii obejmuje różnorodne instytucje oraz organizacje: muzea, dealerów, kolekcjonerów, domy aukcyjne, biennale, targi, czasopisma, krytykę, akademie, ministerstwa, urzędy (wydziały) i prywatne źródła wsparcia finansowego. Termin "sztuka” desygnuje owe instytucje już przez samo definiowanie podmiotów świata sztuki: muzeów jako muzeów sztuki, przez utożsamianie klasy dealerów jako dealerów sztuki, i dalej - kolekcjonerów sztuki (lub dzieł określonego rodzaju), magazyny sztuki, targi 
sztuki, krytykę sztuki, akademie sztuki, ministerstwo sztuki, wydziały sztuki $\mathrm{w}$ urzędach administracji państwowej i terenowej itp. ${ }^{1}$ Świat sztuki ma więc wielu instytucjonalnych podwykonawców. Podstawową ich funkcją, czy też celem, jest odgrywanie różnych ról związanych ze: sterowaniem wytwórczością, wyjaśnianiem, krytyką, studiowaniem, nagradzaniem, dystrybuowaniem dzieł sztuki itp. Cały ów system połączeń, od produkcji, poprzez edukację, po obieg i odbiór, jest jednak wyraźnie zorientowany rynkowo. Dotyczy to także muzeów, które pod koniec $X X$ wieku stanęły wobec wyboru: przekształcenia się $\mathrm{w}$ podmioty rynku, $\mathrm{w}$ ekonomicznym tego słowa znaczeniu, bądź, przeciwnie - odrzucenia mechanizmów rynkowych, co grozi im jednak wypadnięciem z rynku i marginalizacją swojej pozycji $\mathrm{w}$ świecie sztuki. To zignorowanie rozwojowego potencjału rynku, praktyki i teorii marketingu określa się mianem spirali niepowodzeń, kończącej się upadłością lub samolikwidacją, w najlepszym razie wypchnięciem na peryferie (margines) świata sztuki.

Kwestie sieciowych połączeń, w których wspomniane instytucje świata sztuki odgrywają rolę węzłów (hubs) spajających jego struktury, podjęte zostały w wielu pracach wybitnych komentatorów: socjologów sztuki, takich jak: Raymonde Moulin (Le marché de la peinture en France, 1967), Pierre Bourdieu (La Distinction: Critique sociale du jugement, 1979), Howard S. Becker (Art Worlds, 1982), Janet Wolff (Aesthetics and the Sociology of Art, 1983) oraz ekonomistów kultury: Marc Blaug (The Economics of the Art, 1976), William Grampp (Pricing the Priceless: Art, Artists and Economics, 1989), Bruno S. Frey (Arts and Economics. Analysis and Cultural Policy, 2000), David Throsby (Economics and Culture, 2000), Ruth Towse (Cultural Economics, Copyright and the Cultural Industries, 2002). Głównym celem przytoczonych tu autorów było ukazanie relacji pomiędzy różnymi uczestnikami, używając terminologii P. Bourdieu, pola sztuki oraz ról, jakie w nim pełnią, by pomóc nam lepiej zrozumieć zróżnicowane siły kształtujące współczesny świat sztuki.

W latach dziewięćdziesiątych z kolei nastąpił wyraźny wzrost liczby debat poświęconych muzeum jako instytucji realizującej zadania edukacyjne, co prezentowali m.in.: Gail Durbin (Developing Museum Exhibitions for Lifelong Learning, 1996), Bonnie Pitman-Gelles (Presence of Mind: Museums and the Spirit of Learning, 1999), Lisa Roberts (From Knowledge to Narrative: Educators and the Changing Museum, 1997), Georg E. Hein (Learning in the Museum, 1998). Za novum wypada także uznać postulat kształcenia (szkolenia) kadry. Wcześniej wysiłki mające na celu wykorzystanie edukacyjnej roli muzeów

1 S. Feagin, Valuing the Art, [w:] Institutions of Art. Reconsiderations of George Dickie's Philosophy, red. R.J. Yanal, Pennsylvania 1994, s. 55. 
podejmowane były przede wszystkim przez kuratorów i kustoszy, bowiem nie było profesjonalnie wykształconych $w$ tej dziedzinie specjalistów. Przyznanie edukacji tak znaczącej roli $\mathrm{w}$ funkcjonowaniu muzeów jest przede wszystkim zjawiskiem dwudziestowiecznym, równoległym z powstaniem współczesnej teorii rozwoju społecznego, legitymizacją nauk społecznych jako przedmiotów akademickich oraz odrzuceniem klasycznego programu nauczania w szkołach publicznych średniego szczebla² .

Współcześnie edukacja jest jedną z głównych funkcji muzeum, realizowana przez specjalnie ku temu wykształcony personel, współpracujący z kuratorami, projektantami wystaw, działem marketingu i pracownikami innych działów (konserwacji, organizacji wystaw itp.). Na przykład, brytyjscy edukatorzy muzealni prowadzą ponad czterdzieści pięć różnego rodzaju aktywności, nie tylko bezpośrednio związanych z zajęciami edukacyjnymi. Organizują również festiwale aktywizujące lokalną społeczność i konferencje, rozwijają partnerstwo z uczelniami oraz wydziałami miejskimi, nadzorują praktyki studenckie czy wolontariat ${ }^{3}$.

Zauważalny jest też znaczący wzrost: publikacji oraz czasopism poświęconych edukacji muzealnej (np. "Journal of Museum Education", "Journal for Education in Museums", "Museum \& Society”), nowych kierunków studiów związanych z muzealną edukacją, a także profesjonalnych stanowisk dla muzealnych edukatorów.

Jeszcze jedna zmiana jest godna odnotowania, a mianowicie muzea, zwłaszcza w Stanach Zjednoczonych i Australii, przekształciły się w jednostki naukowo-badawcze, co oznacza, że prowadzą własne badania na temat: odbiorców (dokonują ich segmentacji), frekwencji, oceny atrakcyjności realizowanych działań.

Na tle zrekonstruowanych wyżej trendów i zjawisk można sformułować cel niniejszego artykułu, za jaki trzeba uznać osadzenie programów edukacyjnych muzeów w strategii długookresowej współpracy muzeum z odbiorcą. Należy dodać, iż wybrana wersja marketingu odnosi się do relacyjnego marketingu usług i z tego też powodu odbiorca traktowany będzie jako usługobiorca. Tym samym, poza głównym nurtem prezentowanych tu rozważań pozostaje cała sfera zagadnień dotyczących wieloaspektowego statusu sztuki (jako wytworu odzwierciedlającego kontekst społeczny, kulturowy, polityczny, czy ekonomiczny, a także jako matrycy socjalizacji i edukacji).

${ }^{2}$ G.E. Hein, Museum Education, [w:] A Companion to the Museum Study, red. S. Macdonald, Oxford 2006, s. 342.

${ }^{3}$ Tamże, s. 344. 


\section{Zadania stawiane przed muzeami}

Od XIX wieku muzeum ewoluowało z prywatnych Wunderkammern (gabinetów osobliwości), otwartych tylko dla wąskiej grupy oglądających, w instytucję zorientowaną na szeroki krąg odbiorców, choć jeszcze trzy dekady temu większość z nich traktowała siebie jako wyspy kulturowe, które służyły potrzebom kulturalnym elitarnej publiczności. Obecnie, jako część przemysłu kulturowego, walczą o cenne bogactwo we współczesnym społeczeństwie, jakim są rosnące zasoby czasu wolnego. W zawodach tych uczestniczą nie tylko muzea, ale także biura podróży, organizatorzy ekoturystyki, atrakcji tematycznych, sportów widowiskowych, restauracje, centra handlowe itp. To, że muzea nie są instytucjami komercyjnymi, nie oznacza, iż nie działają na rynku i mogą zapomnieć o konkurencji. Dlatego, coraz częściej zajmują się strategicznym planowaniem działań marketingowych po to, by stać się bardziej zauważalnymi w świecie - nie tylko sztuki, a także wzbogacając swoje propozycje, pozyskać odbiorców i zwiększyć przychody. Równocześnie pojawia się wiele innych problemów, z którymi muzea muszą sobie poradzić. Za najważniejszy należy uznać marketingową orientację na widza, która powinna wpływać na postrzeganie nie tylko roli kuratora i dyrektora, ale także odpowiedzialność obu za realizację misji muzeum.

Rodzi się wiele pytań, w rodzaju: kto jest odpowiedzialny za zawartość wystaw (ekspozycje stałe i czasowe)? Jak zadania statutowe korespondują z możliwościami muzeum i najlepiej promują jego wyróżnioną w strategii misję? Kim są widzowie najczęściej odwiedzający muzeum? Czy tu także obowiązuje zasada Pareto, mówiąca, iż $80 \%$ odwiedzających to stali bywalcy? Jakie budować relacje z jednostkowym odbiorcą? Jak skonstruować optymalny program mix, wprowadzający w ekspozycyjną przestrzeń działania interaktywne? Jak konfigurować informację, by była promocją? Jak kształtować urozmaiconą ofertę edukacyjną, by nie zniechęcić, ale zainteresować gości i zaspokoić ich zmieniające się potrzeby? Jakie wskaźniki powinny być stosowane do mierzenia tych dokonań?

Coraz bardziej istotna staje się też kwestia roli nowych mediów (ICT) i technologii wyznaczających standardy publicznego smaku, ale także stosujących cenzurę. Ważny jest również wymóg dostosowania się do demograficznych (nadreprezentatywność widzów seniorów) i globalnych zmian, które przedefiniowują narodową i międzynarodową kulturę. Muzeum sztuki ma bowiem również za zadanie naprawić swoją historię uprzedzeń i wykluczeń. Zobowiązane jest więc dziś do: estetycznej doskonałości i integral- 
ności, dostępności i rozwoju odbiorców oraz szacowania efektywności i transparentności wypracowanych wyników.

Polskie muzea stoją natomiast współcześnie $\mathrm{w}$ obliczu gruntownego przemyślenia swoich podstawowych funkcji: czy przechowywanie jest ważniejsze od udostępniania, a udostępnianie od rozbudzania zainteresowań oraz zmiany postrzegania muzeum jako bastionu elitarności, zarówno wśród widzów, jak i pracowników. Zmuszone są więc, wskutek zmieniających się oczekiwań odbiorców, do proaktywnych działań, rozszerzania zakresu świadczonych usług i wprowadzania nowych propozycji, które będą się przekładać na uznanie opinii publicznej i wymierny wzrost frekwencji odwiedzających. W owych inicjatywach i poszukiwaniach dyrektorzy muzeum oraz personel kierowniczy zaczynają sięgać coraz częściej po nowe strategie edukacyjne, stanowiące jedno z narzędzi marketingu. W tym miejscu należałoby wreszcie sformułować tezę, która głosi, że jeśli zrozumiemy czym jest marketing (i jego wybór), pozwoli nam to rozwiązać problemy łączące się z funkcjonowaniem muzeum. Ponieważ teza ta ma wyraźnie heurystyczną postać, konieczne staje się więc dodatkowe wyjaśnienie odnoszące się do marketingu.

Rozważając bowiem zagadnienie strategicznego wyboru marketingowego, mamy do czynienia z dwoma drogami. Pierwsza, obierana najczęściej przez muzealne supergwiazdy ${ }^{4}$, przybiera kształt strategii konkurencji. W swojej radykalnej wersji odnosi się ona do marketingu transakcyjnego. Podejmowane przez te instytucje formy wspólpracy skierowane są przede wszystkim do innych instytucji: korporacyjnych sponsorów czy patronów.

Alternatywny kierunek polega na zastosowaniu relacyjnej wersji marketingu usług ${ }^{5}$ (Relationship Marketing). Należy wspomnieć, że lista przymiotników dodawanych współcześnie do słowa marketing jest dość długa, bowiem obejmuje: telemarketing pasywny i aktywny, taktyczny i strategiczny, wewnętrzny i bezpośredni, marketing partnerski - by na tym poprzestać, pomijając skądinąd oczywiste określenia „branżowe”. Rację mają ci ekonomiści, którzy twierdzą, że marketing relacyjny nie należy do tej grupy: modnych, krótkoterminowych wersji marketingu. Nie powinno nas mylić przymiotnikowe ujęcie relacji, bowiem celem tej wersji marketingu jest zejście na poziom tego, co podstawowe/źródłowe, a więc odkrywanie niezmiennie podstawowego znaczenia relacji usługowej. Dla muzeum nie będącego supergwiazdą, wybór Relationship Marketing oznaczać będzie

\footnotetext{
${ }^{4}$ Muzea supergwiazdy, to m.in. Muzeum Watykańskie, Prado, Londyńska National Gallery, Rijksmuseum, Louvre, Museum of Modern Art (MoMA), Guggenheim, Tate itp.

${ }^{5}$ Definicja marketingu relacyjnego pojawi się w drugiej części tekstu.
} 
przekształcanie tradycyjnej instytucji muzeum $\mathrm{w}$ organizację usługową, w której pozyskiwanie, zatrzymywanie i współpraca z odbiorcami stawiane jest $\mathrm{w}$ centrum działań muzeum. Ekonomiści zajmujący się problematyką usług uważają, iż nie ma dla sektora usług odpowiedniejszej wersji marketingu, jak marketing relacyjny. Przez skandynawskich naukowców został on wyprowadzony właśnie z - potraktowanej jako wzorzec - relacji usługowej.

Konkludując, obok wielu dotychczasowych funkcji realizowanych przez muzeum (m.in. kolekcjonowania, przechowywania, badania, wystawiania, upowszechniania), pojawia się nowa, polegająca na sprzęgnięciu edukacji z działaniami marketingowymi. Nie zapominamy przy tym oczywiście, że muzeum to także pośrednik (mediator), interlokutor, a przede wszystkim edukator/popularyzator (tzw. museums deliver) oraz miejsce krzyżowania się "produkcji” sztuki (wytwarzania, kreowania) z koncepcjami jej upubliczniania. Muzea świadomie sięgające po tę wersję marketingu czynią to nie tylko w celu zintensyfikowania oddziaływań promocyjnych, ale również osiągnięcia korzyści wyższego rzędu. Pojawiają się one wówczas, kiedy marketing relacyjny staje się podstawą wypracowania koncepcji marketingowego zarządzania (ze strategicznym włącznie).

\section{Jak przekształcić martwe muzeum w atrakcyjne centrum kulturalne}

Współcześnie coraz częściej daje się zauważyć, że instytucje wystawiennicze biorą sobie za cel nie tylko produkowanie kolejnych wystaw, podobnych do wcześniejszych, które cieszyły się zainteresowaniem publiczności. Coraz większą wagę przywiązują do rozmaitości tematów, wzmocnienia więzi z dotychczasowymi odbiorcami oraz wychowania nowej publiczności. Wiele organizacji non profit (w tym również muzea) tworzy więc programy uczestnictwa, mające na celu wzmocnienie powiązań z najbardziej aktywnymi partnerami ${ }^{6}$. Zatem, muzeum zorientowane na odbiorcę musi łączyć dwie perspektywy: odśrodkową - muzeum a odwiedzający oraz dośrodkową - odwiedzający a muzeum. Pierwsza z nich, jak twierdzi Eva M. Reussner, zachodzi pod wpływem polityki kulturalnej w zakresie uczestnictwa w kulturze, integracji społecznej i edukacji nieformalnej, niezależnie od aspektów komercyjnych. Druga z kolei jest kształtowana poprzez posiada-

${ }^{6}$ Ch. Lovelock, S. Vandermerwe, B. Lewis, Services Marketing. A European Perspective, New Jersey 1996, s. 183. 
nie szerokiej oferty, w tym także wypoczynku, rekreacji, przyjemności połączonych $\mathrm{z}$ atrakcjami kulturalnymi ${ }^{7}$.

Skoro zatem strategiczne myślenie o muzeum staje się nieuniknione, to jego konsekwencją powinno być wypracowanie i wprowadzenie koncepcji strategicznego zarządzania o marketingowych podstawach ${ }^{8}$. Pracując nad wspólnym pomysłem stworzenia alternatywy dla narzuconych programów populistycznych ${ }^{9}, \mathrm{w}$ budowaniu nowej tożsamości muzea nierzadko sięgają właśnie po koncepcje marketingu relacyjnego. Pozytywne wykorzystanie tej wersji marketingu $\mathrm{w}$ muzealnictwie zostanie omówione na przykładzie przekształceń, jakim poddano Geological Museum w Londynie ${ }^{10}$. Brak analogii z muzeum sztuk jest pozorny i pojawia się jedynie na poziomie nazwy obu instytucji i posiadanych przez nie zbiorów. Różnice znikają, jeśli odwołać się do problemu, który pozostaje wspólny dla wszystkich muzeów: w jaki sposób podnieść atrakcyjność takiej instytucji, aby przyciągnąć zwiedzających.

Założone $\mathrm{w}$ latach trzydziestych $\mathrm{XX}$ wieku muzeum posiadało bardzo bogate zbiory, uporządkowane według okresów geologicznych skał, minerałów, kamieni szlachetnych, półszlachetnych i było miejscem odwiedzanym głównie przez geologów. Rażący był kontrast między martwotą tego miejsca a pełnymi życia salami sąsiadującego z nim muzeum przyrodniczego. Podjęto więc działania zmierzające do odnowienia ekspozycji, zastosowania bardziej zaawansowanych i innowacyjnych metod wystawienniczych, aby zainteresować i przyciągnąć zwiedzających. Przedsięwzięciom tym towarzyszyła również nowo sformułowana misja: podtrzymać i rozwijać nadal zbiory oraz wykorzystać je w celu odkrywania, zrozumienia, odpowiedzialnego wykorzystania i czerpania radości z obcowania ze światem przyrody. Spektakularnym następstwem realizowanej misji było przekształcenie ekspozycji w „Life Galleries”, które uzyskały nagrodę za perfekcyjny design. Ten pierwszy sukces spowodował połączenie Geological Museum z Natural History Museum. Praktyczna realizacja obranej strategii nie przebiegała jednak łatwo. Wszystkie przeprowadzane przez muzeum badania

${ }^{7}$ E.M. Reussner, Strategic Management for visitor-oriented Musuem. A change of focus, [w:] Museum Management and Marketing, red. R. Sandell, R.R. Janes, London - New York 2007, s. 155.

8 Tamże.

${ }_{9}$ N. Möntmann, Art and its Institutions. Current Conflicts, Critique and Collaborations, London 2006, s. 10-12.

${ }^{10}$ Przedstawiany tutaj kazus, który opracował M. Shulver z Warwick Business School, można znaleźć w: R. Johnston, G. Clark, Service Operations Management: Improving Service Delivery, Pearson Education Limited, 2001, s. 34. 
wskazywały, że zbiory geologiczne są najmniej atrakcyjną częścią muzeum. Były postrzegane jako nudne, monotonne, nie mające nic wspólnego z codziennym życiem. Kiedy zainteresował się nim dział wystaw i edukacji, zmieniono punkt widzenia. O wiele łatwiej jest zainteresować zwiedzających, jeśli - zamiast mówić o zbiorach geologicznych - odkrywa się przed nimi tajemniczy świat wulkanów i fascynujące zjawiska związane z trzęsieniem ziemi, odsłania piękno kamieni szlachetnych i bogactwo form zamkniętych w kamieniu (skamielinach). Okazało się więc, że inaczej należy oceniać wartość zbiorów, definiując ją nie z punktu widzenia posiadanych precjozów, ale bardziej jako osiąganie przez muzeum celu, jakim jest: edukowanie, rozbudzanie entuzjazmu i dawanie przyjemności w poznawaniu osiągnięć nauk o ziemi. Docelową grupą klientów stała się więc młodzież szkół średnich, która dzięki programom telewizyjnym i filmom chciała poznać tajemnice ziemi. Jeśli muzeum zamierzało odpowiedzieć na ten rodzaj przejawianych zainteresowań, nie mogło już swojej działalności ograniczać do eksponowania kolekcji, ale musiało rozbudzać zainteresowania odkryciami naukowymi, pomagać zrozumieć zjawiska geologiczne, kształtować odpowiedzialne wykorzystanie zasobów naturalnych i, co niemniej istotne, dawać przyjemność płynącą z kontaktu z naturą. Kolejnym krokiem w realizowaniu nowej misji była segmentacja populacji młodych odbiorców, z uwzględnieniem zakrojonych na dłuższy czas programów edukacyjnych przeznaczonych dla starszej młodzieży. Innego rodzaju program przygotowano dla najmłodszych; przybierał on postać miniwystaw lub pokazów w formie opowieści, baśni. Logika tych opowieści była ściśle zintegrowana z ogólną tematyką muzeum. Z czasem pojawiły się wystawy interaktywne, zachęcające zwiedzających do eksperymentowania z procesami geologicznymi poprzez własnoręczne zaangażowanie się $\mathrm{w}$ pracę $\mathrm{z}$ eksponatami. Ponieważ muzeum zaczęły odwiedzać całe rodziny, konieczne stało się rozbudowanie powierzchni komplementarnych, takich jak: restauracje, sklepy, pokoje odpoczynku, podobnie jak ma to miejsce w parkach tematycznych. Kiedy pod koniec lat dziewięćdziesiątych zakończono większość zaplanowanych prac, muzeum geologiczne dołączyło do światowej czołówki muzealniczej nie tylko pod względem atrakcyjności ekspozycji, ale i frekwencji.

Przedstawiony kazus ma nie tylko wartość poznawczą, ale i praktyczną. Z podobną problematyką borykają się też muzea sztuki, również współczesnej. Stosując przyjęte tutaj podejście marketingowe, można $\mathrm{w}$ formie podsumowania porównać dwa sposoby funkcjonowania muzeów. Dla podkreślenia różnic pierwsze nazwiemy muzeum tradycyjnym, a drugie - muzeum zorientowanym na odbiorcę. 
Reorientacja muzeum sztuki

\begin{tabular}{|c|c|c|}
\hline Przedmiot działań & Muzeum tradycyjne & $\begin{array}{c}\text { Muzeum } \\
\text { stosujące marketing relacyjny }\end{array}$ \\
\hline Zasadnicza orientacja & zbiory i eksponaty & klienci, odwiedzający \\
\hline Skala doświadczeń & $\begin{array}{l}\text { pojedyncze, } \\
\text { ograniczone do zakresu pod- } \\
\text { stawowego - związanego z eks- } \\
\text { pozycją }\end{array}$ & $\begin{array}{l}\text { wielowymiarowe, spełniające } \\
\text { się w pełnym zakresie usług } \\
\text { (full service) }\end{array}$ \\
\hline Rezultat & poznawczy & $\begin{array}{l}\text { rozbudzenie zainteresowania } \\
\text { i entuzjazm dla sztuki }\end{array}$ \\
\hline Sposób działania & $\begin{array}{l}\text { udostępnianie zbiorów } \\
\text { według kryteriów: kategoria, } \\
\text { chronologia, tematyka }\end{array}$ & $\begin{array}{l}\text { inscenizacja, aranżacja, narracja, } \\
\text { usługi uzupełniające, edukacja } \\
\text { jako sposób włączania, przycią- } \\
\text { gania i zatrzymywania odbiorcy }\end{array}$ \\
\hline Wartość & $\begin{array}{l}\text { odkrywana w pogłębionym } \\
\text { studiowaniu eksponatów, } \\
\text { głównie przez specjalistów (pro- } \\
\text { fessionals) }\end{array}$ & $\begin{array}{l}\text { objawiająca się poprzez działa- } \\
\text { nia wzbogacające i ułatwiające } \\
\text { odbiór, podkreślanie unikato- } \\
\text { wości - zachęta do ambitniej- } \\
\text { szego spędzania czasu wolnego } \\
\text { (leisure) }\end{array}$ \\
\hline
\end{tabular}

Źródło: opracowanie własne na podstawie: G. Clark, R. Johnston, M. Shulver, [w:] Service Operations Management: Improving Service Delivery, R. Johnston, G. Clark, Pearson Education Limited, 2001, s. 34.

\section{Muzeum jako przestrzeń spotkania}

Podejmując problem relacji zachodzących w świecie sztuki, musimy brać pod uwagę dwa podstawowe ich wymiary: ekstensywny (zasięg sieci) oraz intensywny (głębokość i trwałość więzi). Zorientowany na budowanie długookresowych więzi marketing relacyjny znajduje szerokie zastosowanie $\mathrm{w}$ przekształcaniu rutynowych imprez artystycznych w rozbudowane działania, dające ich uczestnikom możliwości wyboru najbardziej odpowiadających im form aktywności. Rzadko zdarza się, aby np. wystawa (usługa wystawiennicza) ograniczająca się do samej prezentacji dzieł, mogła ten warunek spełnić. Długookresowy i złożony cel ma polegać na przekształceniu odbiorcy w wykształconego i lojalnego uczestnika. W każde z działań wbudowane jest zamierzone oddziaływanie promocyjne, ale i edukacyjne przyciągające uwagę i budujące więzi z miejscem, osobami, czy instytucją. „Konsumowanie” jakości estetycznych odbywa się bowiem nie tylko przez ich oglądanie, ale także dzięki szeroko pojętym usługom, otwierającym możliwość uczestniczenia w wydarzeniu czy samym akcie twórczym - obu- 
dowującym je i nadającym znamiona unikatowości. Perspektywa długookresowej współpracy (np. oceniana za pomocą wskaźników retencji), zakładająca powtarzalność/odnawialność relacji, przenosi ciężar zainteresowań z doraźnego zaspokajania potrzeb na „wychowywanie” i edukowanie odbiorcy. Należy ten zamiar interpretować także w kategoriach pozademograficznych.

To właśnie spotkanie jest wyrazem najpełniejszego otwarcia się stron uczestników relacji usługowej, na którym budowana jest nie tylko intencjonalność usługowego świadczenia, ale też dialog umożliwiający długookresową współpracę. W tak zwanych usługach osobistych spotkanie jest stanem czy sytuacją wydarzającą się przede wszystkim w świecie międzyludzkich relacji. W usługach charakteryzuje się ono wyprowadzoną ze wzajemności symetrycznością (usługodawca tak samo zależy od usługobiorcy, jak ten ostatni od pierwszego). Po wtóre, należy uznać, że warunkiem autentyczności spotkania jest jego niewymuszoność. Spotkanie nie wydarza się bowiem kiedy człowiek wchodzi w relację mechanicznie. Człowiek musi być wolny, aby być zdolnym do spotkania. Wolny wybór dotyczący wykonawcy rozciąga się na równie swobodną decyzję o rozstaniu z nim. Usługobiorca powinien zawsze mieć możliwość odejścia; jedyną (bądź najważniejszą) przesłanką ograniczającą taką decyzję powinna być świadomość tego, ile utraci zmieniając usługodawcę ${ }^{11}$. Pewien minimalny poziom sformalizowania sprawia, że relacja usługowa nie będąc przyjaźnią czy znajomością, ma właściwą jej strukturę. Odnawialność relacji usługowych pozwala przyjmować jako coś oczywistego, że nastąpi ciąg dalszy, bowiem relacje tworzy się $\mathrm{z}$ nadzieją i obietnicą przyszłych interakcji (projekcja). Buduje się ją w dialogu, który prowadzi do autentycznego spotkania; dzięki temu świadczenie usługi staje się doświadczeniem czy doświadczaniem udziału w czymś, co ma znaczenie. Wchodzenie $\mathrm{w}$ pogłębione relacje jest równoznaczne $\mathrm{z}$ zapisywaniem historii, w której tworzeniu i zapisywaniu ma swój udział każda ze stron. Dzięki relacjom sytuacja bezpośredniości, dialogu i spotkania umożliwia tworzenie trwalszych więzi i zależności między usługodawcą a usługobiorcą. To właśnie ten rodzaj relacji staje się celem marketingu relacyjnego ${ }^{12}$.

Ogromną różnorodność relacji, ściśle rynkowych i pozarynkowych, należy uznać za zasadniczy czynnik sprawczy powstania, rozwoju i rozszerzającego się zasięgu oddziaływania marketingu relacyjnego. Powstał on $\mathrm{w}$ wyniku zastąpienia transakcji przez interakcję, a następnie interakcji

11 V.A. Zeithaml, M.J. Bitner, Services Marketing, Singapore 1996, s. 172-173.

12 Tamże. 
przez relacje, z jednoczesnym uznaniem relacji usługowej za wzorcową. Wychodząc $\mathrm{z}$ podstawowego założenia, że $\mathrm{w}$ marketingu relacyjnym rzeczywiście chodzi o opłacalne relacje, których dochodowość potwierdza się w długookresowej współpracy, a nie jednostkowej transakcji, ekonomiści podjęli wysiłek zmierzający do ich uporządkowania ${ }^{13}$. Zaproponowana przez E. Gummessona systematyka pozwoliła wyróżnić dokładnie trzydzieści typów relacji (30Rs), wśród nich relacje odniesione do symboli i przedmiotów ${ }^{14}$.

Marketing relacyjny za godne zainteresowania uznał także relacje z klientami niezadowolonymi, które dotąd nie były przedmiotem analiz. W celu uniknięcia wieloznaczności, wypadałoby wreszcie przytoczyć definicję marketingu relacyjnego. Rozumiany jest on jako mobilizacja personelu (zatrudnionego $\mathrm{w}$ instytucjach sztuki), mająca na celu uczynienie $\mathrm{z}$ nabywcy nie tylko współwytwórcę produktu - wartości, ale co więcej - "związanie" go na stałe $\mathrm{z}$ organizacją usługową ${ }^{15}$. Aby sporadyczne kontakty przekształciły się w trwalsze więzi, powinna dokonać się nie tylko „integracja wstecz" (cofnięcie się do aktu tworzenia), polegająca na uczynieniu nabywcy współprojektantem i współwytwórcą produktu (tego, co ma powstać), ale jednocześnie „integracja wprzód” (antycypując przyszłe stany). Należy więc podkreślić obowiązującą $\mathrm{w}$ wyborach i decyzjach marketingu relacyjnego perspektywę czasową. Pozwala ona przeprowadzić klienta nie tylko przez wszystkie szczeble drabiny lojalności ${ }^{16}$, ale także osiągnąć najważniejszy dla miękkiego marketingu relacyjnego cel - wychowanie klienta niezawodnego. Jest to dlatego tak ważne, ponieważ właśnie tacy klienci (lojalni-niezawodni), czyli tzw. „adwokaci” w końcu mogą zostać włączeni w strukturę organizacji usługowej, jaką bez wątpienia jest muzeum. A to oznacza rewolucję w zarządzaniu tą instytucją.

Muzea coraz częściej zmuszone są zabiegać o publiczność za pomocą eksperymentalnych projektów i programów. Istotne jest, by zmieniły swoje podejście do gości, widzów i odwiedzających, traktując ich nie tylko jako konsumentów, ale także jako krytyków, partnerów i współtwórców projektów. Odbiorcy wnoszą bowiem nowe idee, nową energię i nowe znaczenia do realizowanych programów. Powierzchnie muzealne są doskonałą prze-

${ }^{13}$ P. Mudie, A. Cottam, Ustugi. Zarzadzanie i marketing, Warszawa 1998, s. 165.

${ }^{14}$ E. Gummesson, Total Relationship Marketing. Rethinking Marketing Management: From 4Ps to 30RS, Oxford 2002. s. 90.

${ }^{15}$ K. Rogoziński, Nowy marketing ustug, Poznań 2000, s. 84-85.

${ }^{16}$ Drabina lojalności dla marketingu relacyjnego ma większe znaczenie niż segmentacja rynku. Pokazuje ona, jak też - dzięki zaplanowanym działaniom marketingowym - realizowany jest program coraz ściślejszego wiązania nabywcy z instytucją. 
strzenią dla debat, stawiania pytań, sporu, czy eksperymentowania, a nie wyłącznie miejscem objawiania się dozorców kanonu. Coraz popularniejsza staje się koncepcja głosząca, iż edukacja w muzeum oznacza ROZUMIENIE (meaning-making) nie tylko za pośrednictwem obiektów muzealnych oraz sposobu ich prezentacji, ale także za sprawą osobistego doświadczenia/przeżycia odbiorcy i warunków w których do tego dochodzi. Istotne jest więc, twierdzi Teresa Kostyrko, w perspektywie tworzących się nowych możliwości instytucjonalnych, pamiętanie o wielości potrzeb odbiorców, a także rozważne ich traktowanie, które jest zgodne z postulatami właściwie pojmowanego pluralizmu. Albowiem pluralizm wartości stanowi istotę programu upowszechniania sztuki. Jest również dobrym przygotowaniem do przyjęcia zmian w samej sztuce oraz do otwartości na nie ${ }^{17}$.

\section{BIBLIOGRAFIA}

Feagin S., Valuing the Art, [w:] Institutions of Art. Reconsiderations of George Dickie's Philosophy, red. R.J. Yanal, The Pennsylvania State University Press, Pennsylvania 1994.

Gummesson E., Total Relationship Marketing. Rethinking Marketing Management: From 4Ps to 30RS, Butterworth-Heinemann, Oxford 2002.

Hein G.E., Museum Education, [w:] A Companion to the Museum Study, red. S. Macdonald, Blackwell Publishing Ltd., Oxford 2006, UK.

Johnston R., Clark G., Service Operations Management: Improving Service Delivery, Pearson Education Limited, 2001.

Kostyrko T., Skoro stowo się rzekło..., Kultura Współczesna, 2004, 2(40), Narodowe Centrum Kultury, Warszawa 2004.

Lovelock Ch., Vandermerwe S., Lewis B., Services Marketing. A European Perspective, Prentice Hall Inc., New Jersey 1996.

Möntmann N., Art and its Institutions. Current Conflicts, Critique and Collaborations, Black Dog Publishing, London 2006.

Mudie P., Cottam A., Ustugi. Zarzadzanie i marketing, Wydawnictwo Naukowe PWN, Warszawa 1998.

Reussner E.M., Strategic Management for visitor-oriented Musuem. A change of focus, [w:] Museum Management and Marketing, red. R. Sandell, R.R. Janes, Routledge, London New York 2007.

Rogoziński K., Nowy marketing ustug, Wydawnictwo Akademii Ekonomicznej w Poznaniu, Poznań 2000.

Zeithaml V.A., Bitner M.J., Services Marketing, McGraw-Hill, Singapore 1996.

${ }_{17}$ T. Kostyrko, Skoro stowo się rzekło..., Kultura Współczesna, 2004, 2(40), s. 62. 